\title{
NILAI-NILAI KARAKTER PADA LEMBAGA ADAT DESA ADAT SADING SEBAGAI SUMBER PEMBELAJARAN IPS DI SMP NEGERI 5 MENGWI
}

\author{
I Ketut Sumberbudi I Wayan Kertih²,I Putu Sriartha ${ }^{3}$ \\ Program Studi Pendidikan IPS Universitas Pendidikan Ganesha Singaraja
}

Email:Sumberbudi004@gmail.com; iwayankertih@gmail.com;

\begin{abstract}
Abstrak
Penelitian ini bertujuan untuk mengetahui; (1) alasan nilai-nilai karakter sebagai kearifan lokal Desa Sading masih tetap bertahan di tengah-tengah perkembangan yang ada; (2) nilai-nilai kearifan lokal pada Lembaga Adat Desa Sading yang sesuai dengan nilai-nilai karakter dalam pembelajaran IPS di SMP Negeri 5 Mengwi; dan (3) cara mengintegrasikan nilai-nilai karakter sebagai nilai-nilai kearifan lokal pada Lembaga Adat Desa Sading sebagai sumber pembelajaran IPS di SMP Negeri 5 Mengwi. Penelitian ini menggunakan rancangan penelitian kualitatif dengan pendekatan etnopedagogi. Penelitian ini dilakukan di Desa Sading dan di SMP Negeri 5 Mengwi. Subyek dalam penelitian ini adalah para prejuru Desa Sading, tokoh-tokoh masyarakat, para pemangku, sekaa teruna-teruni, para guru IPS , siswa dan Kepala Sekolah di SMP Negeri 5 Mengwi, sedangkan yang dijadikan sebagai objek penelitian adalah nilai-nilai karakter yang ada di Desa Sading. Penentuan informan dalam penelitian ini dilakukan dengan teknik purposive sampling dan untuk pengumpulann data digunakan teknik wawancara, observasi dan studi dokumen. Untuk pengujian kesahihan data digunakan triangulasi data, triangulaasi metode dan triangulasi teori. Data dianalisis dengan cara analisis data kualitatif Miles dan Huberman. Adapun hasil yang diperoleh dari penelitian ini adalah bertahannya adat dan budaya di Desa Adat Sading, karena dresta-dresta yang ada yang diwarisi secara turun temurun dan tetap diipelihara dan diadaptasi sesuai dengan perkembangan yang ada dan dituangkan dalam awig-awig desa. Terdapat 8(delapan) nilai-nilai kearifan lokal yang sesuai dengan nilai-nilai luhur (adi luhung) menjadi media yang sangat strategis dalam pembelajaran nilainilai karakter yang dapat dintegrasikan dalam pembelajaran IPS sebagai sumber pembelajaran yang dituangkan dalam RPP ( Rencana Program Pembejaran) sehingga pembelajaran IPS menjadi lebih bermakna.
\end{abstract}

Kata Kunci: Nilai-nilai Karakter, Lembaga Adat, dan Sumber Pembelajaran Ilmu Pengetahuan Sosial.

\section{Abstract}

This study aims to determine; (1) the reasons for character values as the local wisdom of Sading Village still survive in the midst of existing developments; (2) local wisdom values in the Adat Village Sading Institution that were in accordance with the character values in social studies learning at Mengwi 5 Public Middle School; and (3) how to integrate character values as local wisdom values in the Sading Village Customary Institution as a source of social studies learning in Mengwi 5 Public Middle School. This study used a qualitative research design with ethopedic approach. This research was conducted in Sading Village and in SMP Negeri 5 Mengwi. The subjects in this study were the Sading village prejuru, community leaders, stakeholders, all-teruni-teruni, social studies teachers, students and school principals in Mengwi Public Middle School 5, while the ones used as research objects were existing character values in Sading Village. Determination of informants in this study was carried out by purposive sampling technique and to collect data used interview techniques, observation and document study. To test the validity of the data used data triangulation, method triangulation and theory triangulation. Data were analyzed by qualitative data analysis of Miles and Huberman. The results obtained from this study are the persistence of customs and culture in the Village of Adat Sading, because the drafts that have been inherited from generation to generation and remain preserved and adapted according to existing developments and poured in the village awigawig. There were 8 (eight) values of local wisdom that were in accordance with noble values (adi luhung) into a very strategic media in learning character values that can be integrated in social studies learning as a source of learning as outlined in the RPP (Plan of Charter Program) so that social studies learning becomes more meaningful.

Keywords: Character Values, Customary Institutions, and Social Sciences Learning Resources. 


\section{PENDAHULUAN}

Bali merupakan daerah yang sangat terkenal di dunia baik karena pariwisata maupun kearifan lokal dan budayanya. Bali yang masih sangat memegang teguh budaya dan kearifan lokalnya menjadi daya tarik tersendiri bagi wisatawan untuk datang berkunjung ke Bali. Gejala mendasar yang dihadapi dan dirasakan oleh masyarakat Bali dewasa ini adalah perubahan sosial budaya yang sangat cepat, perubahan sosial budaya terjadi karena adanya kontak udaya antar negara. Kontak budaya dapat dimaknai sebagai pertemuan antara nilai-nilai baru dengan nilai-nilai lama yang saling mendominasi dan sangat berpengaruh dalam kehidupan masyarakat. Hal ini dapat terlihat berbagai contoh degradasi moral seperti korupsi, pola hidup konsuftif, hedonisme, demontrasi, berbagai bentuk terorisme, pencemaran lingkungan, individualisme, sulitnya menumbuhkan kepercayaan terhadap kejujuran masyarakat dan lain-lain. Hal ini akan memunculkan karakter manusia Indonesia cendrung menyimpang dari nilai-nilai karakter Bangsa Indonesia. Dengan melestarikan kearifan Ikal suatu bangsa, diharapkann dapat membangun karakter individu khsususnya dan bangsa Indonesia pada umumnya menjadi lebih baik.. Pada intinya, perubahan pada masyarakat Bali terjadi karena gelombang modernisasi dan globalisasi yang telah memperkenalkan nilai baru dalam lingkungan tradisi Bali.

Budaya memiliki nilai-nilai yang senantiasa diwariskan, ditafsirkan, dan dilaksanakan seiring dengan proses perubahan sosial kemasyarakatan. Pelaksanaan nilai-nilai budaya merupakan manisfestasi dan legistrasi masyarakat terhadap budaya. Eksistensi budaya dan keragaman nilai-nilai kebudayaan yang dimiliki oleh bangsa Indonesia merupakan sarana untuk mamebangun karakter warganegara baik yang berhubungan dengan karakter privat maupun karakter publik.

Menurut Geertz (1992:5) yang dikutif oleh Rasid Yunus (2014) kebudayaan adalah "pola dari pengertian-pengertian atau makna yang terjalin secara menyeluruh dalam simbolsimbol yang di transumsikan secara teoritis, suatu sistem mengenai konsepsi-konsepsi yang diwariskan dalam bentuk-bentuk simbolik yang dengan cara tersebut manusia berkomunikasi, melestarikan dan mengembangkan pengetahuan dan sikap mereka terhadap kehidupan". Geertz menekankan bahwa kebudayaan merupakan hasil kerja manusia yang dapat mengembangkan sikap mereka terhadap kehidupan dan diwariskan satu generasi ke generasi berikutnya melalui proses komunikasi dan belajar agar generasi yang diwariskan memiliki karakter yang tangguh dalam menjalankan kehidupan.

Bali mengalami pergeseran budaya yang datang dari timur dan barat, sehingga menimbulkan adanya perubahan-perubahan namun pada hakikatnya perubahan yang ditimbulkan akibat pertemuan budaya tersebut belum begitu berarti, karena masyarakat Bali masih bercorak kolektif, komunal dan ritualistik. Namun demikian, seiring dengan makin eratnya terpaan konsumerisme dan materialisme, kini perilaku orang Bali juga sudah menjadi semakin individualistis, asosial, bahkan menunjukan sifat-sifat hedonis pada sebagian masyarakat. Menghadapi kondisi ini menjadi sebuah keniscayaan bagi para orang tua, dan merupakan sebagai rujukan dalam pendidikan guna membentuk karakter manusia Bali.

Karakter adalah serangkaian kualitas, atau nlai yang membentuk pikiran, aksi, reaksi dan perasaan kita. Orang-orang yang dengan karakter kuat: (1) menunjukan era belas kasihan, (2) jujur dan adil, (3) disiplin diri dalam masyarakat dan mencapai tujuan, (4) membuat penilaian yang baik, (5) menunjukakan rasa menghormati, (6) menunjukkan keberanian dalam menegakkan kebenaran, (7) memiliki rasa tanggung jawab yang tinggi, (8) merupakan warga negara yang baik yang memeperhatikan masyarakat mereka, dan (9) memelhara rasa hormat. Karakter bangsa merupakan jati diri bangsa yang merupakan kumpulan dari karakter-karakter warga negaranya. Sesuai dengan pendapat Endang Ekowarni (2010)secara universal berbagai karakter dirumuskan sebagai nilai hidup bersama berdasar atas pilar : kedamaian, menghargai, kerjasama, kebebesan, kebahagiaan, kejujuran, kerendahan hati, kasih sayang, tanggung jawab , kesederhanaan , toleransi , dan

persatuan. Demikian juga Abun Rosadi (2010) yang dikutip Suci Budiwati (2011) merumuskan karakter bangsa , sebagai berikut: Religius, jujur, toleransi, disiplin, kerja keras, kreatif, mandiri, demokratis, rasa ingin tahu, semangat kebangsaan, cinta tanah air, 
menghargai prestasi, bersahabat berkomunikasi, cinta damai , gemar membaca, peduli lingkungan, peduli sosial, an tanggung jawab.

Di tengah-tengah arus modernisasi dan perkembangan yang ada, nilai-nilai kearifan lokal yang ada di Desa Sading khususnya pada lembaga adat masih tetap dipertahankan dan diadaptasi sesuai dengan perkembangan yang ada di masyarakat. Keberadaan Banjar Pemetang Dasan yang diwarisi secara turun temurun sebagai dresta kuno yang selanjutnya ditulis dalam awig-awig Desa Adat Sading oleh prajuru adat seperti PancaTanda, Bendesa Adat, Kelian Adat maupun kelian Banjar adalah sebagai wadah di dalam menjalankan kegiatan adat dan budaya di Desa Sading, yang berlokasi di Kecamatan Mengwi, Kabupaten Badung. Berdasarkan pada hasil wawancara yang dilakukan bersama penglingsir dan sekali tokoh adat Desa adat Sading A.A Gede Agung (80 Tahun) selaku mantan Bendesa Adat Sading dan tokoh Puri Sading menyebutkan kegiatan adat dan budaya di Desa Sading tetap memakai lembaga adat sebagai payung adat dalam menjalankan seluruh aktivitas adat namun tetap adaktif sesuai dinamika yang ada dalam masyarakat.

Menyadari pentingnya kearifan lokal dan kebermanfaatannya bagi kelangsungan dan kehidupan manusia akan sangat bijak jika masyarakat kembali kepada jati diri mereka melalui perencanaan kembali dan rekonstruksi nilai-nilai kearifan lokal. Dalam kerangka tersebut upaya yang perlu dilakukan adalah menguak nilai-nilai atau makna substantif kearifan lokal suatu dapat mentransformasikannya kepada masyarakat. Dalam upaya mentrasformasikan makna substansi nilai-nilai kearifan lokal akan sangat efektif jika nilainilai kearifan lokal dapat dibelanjarkan pada dunia pendidikan.

\section{METODE}

Penelitian ini menggunakan rancangan penelitian kualitatif dengan pendekatan etnopedagogi. Penelitian ini dilakukan di Desa Sading dan di SMP Negeri 5 Mengwi. Subyek dalam penelitian ini adalah para prejuru Desa Sading, tokoh-tokoh masyarakat, para pemangku, prejuru dinas, sekaa teruna-teruni, para guru IPS , siswa dan Kepala Sekolah di SMP Negeri 5 Mengwi, sedangkan yang dijadikan sebagai objek penelitian adalah nilai-nilai karakter yang ada di Desa Sading. Penentuan informan dalam penelitian ini dilakukan dengan teknik purposive sampling dan untuk pengumpulann data digunakan teknik wawancara, observasi dan studi dokumen. Untuk pengujian kesahihan data digunakan triangulasi data, triangulaasi metode dan triangulasi teori. Data dianalisis dengan cara deskriftif kualitatif yang dikembangkan oleh Mile dan Huberman (1992) melalui langkahlangkah pengumpulan data, reduksi data, menyajikan data dan penarikan kesimpulan.. Dari analisis data yang diperoleh dalam penelitian ini dimana fungsi Banjar Pemetang dasan dalam melestarikan adat dan budaya di Desa Adat Sading sebagai nilai-nilai kearifan lokal yang dituangkan dalam awig-awig Desa Adat Sading dalam mengatur masyarakat/krame desa adat Sading dalam mempertahankan adat dan budaya dalam menghadapai tantangan atau era global.

\section{HASIL DAN PEMBAHASAN}

\section{Eksistensi Banjar Pemetangdasan dalam pelesatrian adat dan Budaya}

Desa Sading adalah salah satu desa yang terletak di kecamatan Mengwi yang masih tetap mempertahankan aktivitas sosio kultural masyarakatnya berupa nilai-nilai kearifan lokalnya. Kearifan lokal yang melekat pada diri masyarakat Desa Sading tidak lepas dari dresta yang ada yang diwariskan secara turun temurun. Kriyantono (2014) dalam bukunya yang berjudul "Teori Public Relations Perspektif Barat dan lokal Aplikasi Penelitian dan Praktik" yang dikutif Atmadja,2017:40) menyatakan kearifan lokal (lokal wisdom atau lokal genius) adalah :

"Pemikiran atau ide setempat (lokal) yang mengadung nilai-nilai bijaksana, kearifan, kebaikan, yang terinternalisasi secara turun-temurun (mentradisi). Nilai-nilai tesebut dipercaya mengandung kebenaran sehingga diiukuti oleh anggota masyarakatnya. Kearifan lokal ini bisa disebut nilai-nilai luhur (adhi luwung) masyarakat yang berfungsi sebagai landasan filsafat perilaku yang baik menuju harmonisasi". 
Berlandasan itu, nilai-nilai hidup yang tercermin dalam masyarakat desa Sading menjadi suatu bentuk kearifan yang memiliki mamfaat bagi masyarakat. Kebiasaan hidup tersebutlah selanjutnya membentuk nilai-nilai kearifan lokal sebagai wujud perilaku masyarakat dalam berinteraksi dalam suatu komunitas dengan mewadahi diri dalam lembaga sosial (adat) dalam mencapai kebutuhannya menuju masyarakat yang harmonis.

Desa Sading pada saat ini cukup luas membentang dari utara ke selatan, sehingga sering juga ada istilah Sading desa, Sading Negara dan Sading Manyar (yang dimaksud Sading Umahnyar), biasanya yang dimaksud Sading Desa adalah Banjar Dajan Bingin dan Banjar Delod Bingin.

Desa Sading terdiri dari tiga belas banjar yang kemudian dikelompokan menjadi lima Pemetang Dasan. Istilah Pemetang dasan hanya terdapat di Desa Sading, di desa-desa lainnya tidak ada terdapat istilah Pemetang Dasan.

Berdasarkan uraian di atas, keberlangsungan adat dan budaya dengan tetap berpegang pada nilai-nilai adi luhung atau dresta-dresta yang ada dan adanya kesadaran semua untuk memelihara serta tinut dengan melibatkan semua komponen yang ada dalam masyarakat,seperti konsep pemetang dasan yang ada dan sangat dihormati.

Wilayah pemetang Dasan itu dibentuk adalah suatu tugas khusus yaitu nyanggra piodalan dan segala keperluan di pura-pura penyungsungan desa Sading sesuai pembagian masing-masing. Jadi Pemetang Dasan itulah yang nyanggra ilen-ilen piodalan yang didahului dengan kegiatan perencanaan (ngerembug) atau sangkep dan dengan segala keperluan dan prosesinya dipertanggungjawabkan oleh Pemetang Dasan penyanggra tersebut.Adapun pembagian Pemetang Dasan itu adalah sebagai berikut: 1)

1. Pemetang Dasan Puseh - Pengalasan

Pemetang Dasan Puseh- Pengalasan terdiri dari dua banjar, yaitu: banjar puseh dan Bnajar Pengalasan. Pemetang Dasan Puseh -Pengalasan mendapat tugas nyanggra segala prosesi dan ilen-ilen piodalan di Pura Gede Puseh.Segala apapun yang diperlukan dan acara apapun yang akan dilaksanakan dalam piodalan di pura Gede puseh ditanggung dan demikian juga dilaksanakan oleh pemetang dasan puseh ddengan berkoordinasi dengan Kelian adat Desa Sading.

2. Pemetang Dasan Negara

Pemetang dasan Negara terdiri dari dua banjar yaitu; banajar Negara Kaja dan Banjar Negara Kelod. Pemetang Dasan Negara mendapat tugas nyanggra piodalan pura Dalaem Penataran. Demikian juga segala prosesi piodalan dan segala sesuatu yang diperlukan, untuk itu dipertanggung jawabkan oleh Pemetang Dasan Negara. Disamping bertugas nyanggra di Pura Dalem Penataran, Pemetang Dasan Negara mempunyai tugas lagi yaitu menyelenggarakan piodalan di Pura Gede Batan Ancak, yang sering juga disebut Pura Gede Negara. Pura Gede Batan Ancak dibangun oleh masyarakat Pemetang Dasan Negara adalah untuk penyawangan Pura Kahyangan Tiga, karena alasan jarak.

3. Pemetang Dasan Dajan Bingin

Pemetang Dasan dajan Bingin terdiri dari tiga banjar yaitu ; Banjar Jeroan, Banjar Sengguan dan Pasekan. Pemetang Dasan dajan Bingin mendapat tugas nyanggra segala upkara piodalan di Pura Dalem Tunggkup dilaksanakan dan dipertanggungjawabkan oleh Pemetang Dasan Dajan Bingin.

\section{Pemetang Dasan Delod Bingin}

Pemetang dasan delod Bingin terdiri dari tida banajar adat yaitu; banjar Pekandelan danginan, banjar Pekandelan Dauhan dan banjar Karangsuwung. Pemetang Dasan delod Bingin dapat tugas nyanggra piodalan dan segala prosesinya di Pura Desa. Demikian juga segala tugas dan piodalan di Pura Desa dipertanggungjawabkan oleh Pemetang Dasan Delod Bingin.

5. Pemetang Dasan Umahnyar

Pemetang dasan Umahanyar adalah pemetang Dasan yang termuda ,. Mengemban Pemetang dasan ini terdiri dari tiga banjar adat yaitu; Banjar Negari, Banjar Madya sari dan Banjar Ujung sari. Pemetang Dasan Umahnyar dapat tugas 
nyanggra piodalan di Pura Kahyangan. Segala prosesi piodalan dan keperluan untuk itu dipertanggungjawabkan oleh Pemetang Dasan Umahnyar.Disamping mengemban tugas desa, Pemetang Dasan Umahnyar juga melaksanakan kewajibannya yaitu ngodalan di Pura Dalem Kediri. Tugas lain yang diemban adalah dalam rangka ngiring pelungan Ida Bhatara Ratu Gede ke pura-pura di Sading dan terutamanya kalau lunga ke luar Desa Sading seperti ke Pura Tua Tabanan, Ke Pura Baru,ke Pura Luhur Natarsari Apuan Tabanan, ke Pura Luhur Pucak Kembar Pacung Tabanan. Tugas dijalankan dengan suatu kesadaran yang tinggi dan keyakinan yang sangat mendalam, semua tugas yang diemban dianggap sebagai ayahan yang sangat membahagiakan, sehingga tidak ada suatu gejolak yang berarti dalam ngayah, ngiring ratu Bhatara.

Dalam hubungannya dengan tugas dan tanggung jawab Banjar Pemetang dasan di Desa Sading terkait dengan keunikan yang ada di Desa Sading yakni adanya Pura Tri Kahyangan berjumlah 5, artinya 3 Pura Kahyangan Desa dan 2 Pura Dalem Kahyangan yang terletak disebelah selatan Desa Sading dan di sebelah barat laut Desa Sading (dajan desa). Hal ini menjadi unsur keseimbangan dan persatuan yang ada di Desa Sading yang secara realita (sekala) antar pura yang ada di Sading saling keterkaitan histori terbukti dengan adanya Upacara Saling Kelungin (saling ngerauhin) jikalau ada Upacara/odalan di masing-masing pura.

Kearifan lokal Banjar Pemetangdasan tidak hanya aktivitasnya di ranah pahrayangan akan tetapi juga menyangkut aktivitas di ranah pawongan dan palemahan. Hal ini digambarkan atau dideskripsikan dari nilai-nilai kearifan lokal yang ada di Desa Sading sebagai berikut: Pemetang dasan sebagai dresta kuno sekaligus dresta desa yang ada di Desa Adat Sading yang terpelihara secara turun temurun dan tertuang dalam awig-awig Desa Sading didalam mengorganisasikan dan mengelola adat dan budaya di Desa Sading .

Pemetang dasan dalam aktiviatasnya bersumberkan pada ajaran agama Hindu yakni Tri Hita Karana, yakni keharmonian pada parhyangan , pawongan dan palemahan yang dalam aktualisasi sosio kemasyarakatan tergambar dalam banjar pemetang dasan (pembagian wilayah dan tanggung jawab), dulun desa (orang-orang yang berhasil dan dipercaya di tingkat desa)) panca tanda (badan yang memilih kelian desa adat dan menampung aspirasi), sapta penghulu (penasehat kelian adat di banjar adat), tindih (setia), bhakti ( berserah diri), sweca (iklas), nguopin ( saling bantu antar sesama manusia), ngayah ( gotong -royong yang secara iklas di pura atau di grya /puri), mekemit ( bermalam suntuk), maegebagagan (wujud peduli sosial untuk menemani anggota keluarga yang berduka), memunjung (membawa sesajen kepada sesama kerabat keluarga), melancaran (keliling desa untuk keselamatan desa) , mepeed/melelod ( membawa sesajen/gebogan sebagai wujud bhakti kepada Tuhan), ngejot (saling memberi dan menerima) maupun ungkapan ungkapan tradisional seperti ; eda ngaden awak bisa, depang anake ngadanin (jangan sombong), puntul-puntule tiuk yen suba sangih pasti mangan (jangan putus asa untuk belajar), rwe bhineda (keberagaman), celebingkah beten biu, gumi linggah ajak liu ( mengakui keberagaman), mekecuh marep menek (instrosfeksi), karma phala (hukum sebab akibat dari perbuatan yang kita lakukan), Tri Hita Karana (tiga penyebab keharmonisan), metilesang dewek (tahu diri), muani negen, luh nyuun (kesetaraaan gender), mesikut di awak (introsfeksi), jele melah pada gelahang ( rasa kebersamaan), Paras-paros (tenggang rasa), asah,asih, asuh (hak dan kewajiban yang sama), menyama braya (persaudaraan), masidhikara (persatuan), sagilik saguluk (bersatu padu secara bulat dan utuh), nindihin patut (membela kebenaran), Lascarya (iklas).

\section{Nilai-nilai karakter yang terkandung pada lembaga desa adat Sading}

Masyarakat Desa Sading mempunyai kearifan lokal yang sangat potensial untuk dijadikan cerminan sikap dan perilaku (karakter) yang sudah terbentuk dan terstruktur dalam diri dan institusi yang mengaturnya sebagai yang disebut sebagai lembaga adat Desa Adat Sading. Melalui lembaga adat yang ada semua kebutuhan untuk mencapai sesuatu tujuan hidup dapat tercapai dengan sendirinya . hal ini mengingat kompleksitas kebutuhan dengan varian tingkah laku yang berbeda-beda. Maka dapat diyakini nilai-nilai pendidikan karakter 
dapat diwujudkan lewat kearifan lokal sebagai modal budaya (Atmadja,2017: 69). Gejala ini dapat dicontohkan pada nilai kejujuran. Kejujuran bearti seseorang tidak berbohong-berpikir, berkata,dan bertindak yang baik dan benar patokannya agamaan/atau tata aturan lainnya.Jika orang tidak jujur , misalnya korupsi maka sesuai dengan hukum karma phala cepat atau lambat akan mendapatkan buahnya- buah negatif seperti penjara. Penanaman ini dapat dilakukan melalui kearifan lokal yang berbunyi, yakni " apa ane kepula, keto ane kalap" yang artinya apa yang kita tanam, begitulah yang akan kita petik. Hal ini mengajarkan agar selalu berbuat kebaikan - jujur agar dapat memetikbuah kebaikan.

Demikian halnya Desa Sading menunjukkan nilai-nilai kearifan lokal yang ada di Desa Sading memiliki sistem nilai yang membangun kepribadian masyarakatnya yang mencerminkan sikap dan perilaku yang bertindak sesuai dengan kaidah-kaidah dan dimensi sosial yang ada. Adanya konsep Banjar Pemetang dasan sebagai konsep pembagian kewilayahan yang sesungguhnya adalah distribusi hak dan kewajiban masing-masing banjar adat yang ada di desa Sading terhadap tugas dan tanggung jawab desa adat yang dikerjakan secara bersama-sama melalui Banjar Pemetang dasan. Banjar Pemetang dasan itu sendiri dalam proses aktivitasnya mencakup tiga aspek baik ranah relius(parhayangan), ranah kemanusiaan (pawongan) maupun ranah lingkungan (palemahan). Semua ranah tersebut masuk atau terwadahi dalam lembaga dat desa Sading yang tersebut dalam awigawig desa adat Sading.

Dari hasil kajian mengenai kearifan lokal yang terdapat di Desa Sading, setidaknya teridentifikasi 8(delapan) nilai karekter yang dianggap relevan untuk dijadikan sebagai sumber pembelajaran dan pedoman / pembekalan bagi tenaga pendidik ( guru), guna dilakukan pengintegrasian pada pembejaran IPS, sehingga nantinya dari pengintegrasian tersebut, bisa memberikan rangsangan bagi peserta didik untuk menanamkan nilai-nilai karakter yang sifatnya local genius dan kearifan lokal dalam pembentukan karakter bangsa. (Atmadja, 2017 34).Adapun nialai-nilai karakter yang terdapat pada lembaga desa adat sading, dapat diidentifikasi dari tradisi-tradisi lisan dalam praktek kehidupan sehari-hari, ungkapan-ungkapan tradisional serta adanya Panca Tanda, Dulun Desa , Kelian banjar adat, pemetang dasan. Adapun kedelapan nilai - nilai karakter tersebut yaitu : (1) Nilai ketuhanan (religius), (2) Toleransi, (3) Demokratis, (4) Tanggung Jawab, (5) Peduli sosial, (6) Berpikir kritis/rasa ingin tahu, (7) menyelesaikan konflik secara damai (8) kemauan dan kemampuan berpartisipasi dalam masyarakat/cinta Tanah air

Dari kedelpapan nilai-nilai karakter yang terdapat pada Desa Adat Sading dapat dijelaskan sebagai berikut: 1) Nilai ketuhanan (religi), Nilai ketuhanan pada dasarnya menjadi cerminan bagi setiap insan/individu masyarakat Desa sading yang mempercayai akan mamfaat nilai ketuhanan tersebut dalam memberikan kesehimbangan dan keteladanan bagi kehidupan yang dilakoni setiap harinya.Nilai-nilai ketuhanan dijadikan sebagai landasan, pedoaman, panutan dan tuntunan untuk bersikap dan berperilaku bagi sesama krama yang ada di desa Sading maupun dalam berinteraksi dengan dan/atau luar lingkuangan desa Sading.Kuatnya pengaruh nialai-nilai ketuhanan pada diri masyarakat Desa Adat sading, yang terbawa secara turun-temurun, yang menjadi terwariskan. Kesatuan antara agama, adat dan budaya serta tradisi yang hidup di desa sading dijadikan sebagai satu kesatuan sehingga membentuk nilai - nilai bhakti, sweca, ngayah , ngiring , sesuhunan, lunga , melancaran, mepeed/melelod, pendet wali yang diorganisir dalam Banjar Pemetang dasan. Banjar Pemetang dasan yang diketahui tidak hanya bergerak dalam ranah relegi , akan tetapi juga dalam ranah pawongan maupun palemahan yang didalamnya mengajak keharmosisan dalam masyarakat dalam suasana keberagaman.Keberagaman yang diaktualkan dalam konsep menyama braya, terhadap penganut keyakinan/agama yang berbeda dikembangkan sikap toleransi. Nilai ketuhanan (religius)yang melekat pada masyarakat Desa Sading dapat membentuk sikap dan perilaku (karakter) masyarakatnya untuk berbuat lebih positif melalui pengamalan rasa bhakti dan eling kepada Tuhan sehingga tercipta keharmonisan antar ssama manusia dengan meneriam perbedaan yang ada, 2) Menghargai pendapat (nilai demokrasi), Menghargai pendapat (demokrasi0 ini berkaitan erat dengan ikut berpartissipasinya semua masyarkatnya untuk ikut andil dalam membentuk/membina masyarakatnya sendiri guna memberikan suatu ide dan gagasan yang 
dimiliki. Pengimplementasian nilai demokrasi ini terlhat pada masyarakat sading yang sangat menghormati perbedaan yang ada. Tidak memandang kelompok banjar yang jumlah kepala keluarganya banyak atau sedikit, melainkan mereka dirangkul dan duduk bersamasama membangun dan menciptakan suasana tentram, karena kita memandang sama mereka semua sehingga mempunyai hak dan kewajiban untuk memberikan pendapat secara tebuka maupun menerima pendapat. Nilai demokrasi terlihat dalam aktivitas seharihari yang dilakoni oleh masyarakat Sading yang terwadahi dalam lembaga adat desa Adat Sading. Aktivitas sangkep/paum yang dihasilkan dalam bentuk perarem baik ditingkat dadia, banjar maupun desa maupun dalam wadah Panca Tanda sebagai DPR nya desa adat yang akan menampung dan menyampaikan aspirasi warga untuk kemajuan desa. Kebermamfaatan akan nilai Demokrasi ini juga tidak terlepas dari kehidupan sehari-hari melalui ungkapan-ungkapan tradisional seperti : a) celebingkah beten biu yang artinya gumi linggah ajak liu, b) belahan pane belahan paso, ade kene ada keto yang artinya keberagaman, c) nyama braya maupun d) sagilik saguluk salunglung sabayantaka yang artinya permukatan bersama dengan penuh kekeluargaan. Nilai-nilai ini tercermin dan terimplementasi ke dalam beberapa tindakan , yaitu masyarakat berhak memperjuangkan kepentingan yang terdapat di lingkungan sosial mereka, memperoleh hak yang sama untuk menentukann kebijakan yang ada serta aktif dalam memberikan ide dan gagasan.

Keterlibatan kompoenen-komponen yang ada dalam masyarakat untuk secara bersama-sama memberikan solusi terhadap suatu hal karena ucapan sepele sehingga menimbulkan ketegangan kecil yang akan berdampak cepat, maka diperlukan langkah segera untuk penyelesainnya.

Berkenaan dengan penyaluaran aspirasi dari warga masyarakat (krama adat) di Desa Adat Sading sudah disiapkan media penyalur aspirasi baik ditingkat banjar adat maupun ditingkat desa adat. Untuk ditingkat banjar adat atau pemetang dasan ditangani oleh Kelian Adat di masing-masing banjar adat sedangkan untuk ditingkat desa adat diwadahi lewat Panca Tanda sebagai lembaga yang menyelenggarakan pemilihann Kelian Desa adat dan sebagai badan yang membuat garis - garis besar program kerja seorang bendesa adat.

Sistem musyawarah yang dilakukan dalam bentuk sangkep/paum baik ditingkat banjar adat maupun ditingkat desa adat, dadia, sekaa teruna/i, kelompok lansia dan lainlain dalam penyaluran pendapat dan permasalahan yang ada untuk diselesaikan secara kekeluargaan .hal ini memberikan indikasi penghargaan atas hak dan martabat manusia, 3) Peduli akan sesama (peduli sosial), Kepedulian sosial adalah perasaan betranggung jawab atas kesulitan yang dihadapi oleh orang lain, dimana seseorang terdorong untuk melakukan sesuatu untuk mengatasinya. Kepedulian sosial dalam kehidupan masyarakat lebih kental diartikan sebagai perilaku baik seseoarang terhadap orang lain sekitarnya.Kepedulian sosial di Desa Adat Sading sudah menyatu dan mentradisi dalam kehidupan masyarakat tidak saja di ranah pawongan dan pelemahan , akan tetapi juga di ranah parhayangan. Di ranah pawongan berjalan tradisi medelokan atau mejenukan, nguopin, megebagan, di ranah pelemahan diwujudkan dengan tumpek uye, tumpek wariga,mecaru dan ranah pahrahyangan diwujudkan dengan dana punia atau ngayah. Rasa kepedulian sosial yang begitu hidup di Bali dan di desa Adat Sading secara konseptual didasarkan pada kehidupan saling memberi dan menerima sehingga tercipta kehidupan yang saling asah, asih dan asuh

Dari tradisi-tradisi yang ada pada masyarakat desa adat Sading diharapkan dapat memberi dan pedoman bagi tenaga pendidik ( guru) untuk membentuk watak /karakter peduli sosial yang tidak saja diktualisasikan bersama temen di sekolah akan tetapi juga bisa diterapkan dan ternbentuk dimanapun mereka berada, 4)Menerima dan memehami perbedaan kultur dalam masyarakat (Toleransi), Keadaan masyarakat sading dewasa ini dengan adanya perkembangan yang ada, Desa sading sangat menjadi pilihan sebagai daerah pemukiman mengingat dari segi letak syang sangat strategis baik ke Denpasar, ke Tabanan ataupun ke Kuta yang bisa melalui Desa sading sebagai jalan singkat.Kondisi seperti ini mau tidak mau akan menjadi banyak pilihan bagi masyarakat pun demikian mengundang mereka untuk memilih sading sebagai tempat tinggal. 
Hal ini menyebabkan Sading semakin ramai dan akibatnya beragam perbedaan /pilihan yang ada di dalamnya, utamanya agama. Masyarakat desa sading selaian sebagaian besar beragama Hindu juga ada yang beragama Kristen terbukti ada empat gereja , yakni di Banjar Puseh, di banjar Pekandelan, di Banjar Karangsuung dan di banjar Negara kaja. Sedangkan untuk penduduk yang beragama yang lain seperti agama Islam dan Budha ada juga di sekitar perumahan-perumahan yang ada di Desa sading.

Khusus penduduk yang beragama Kristen, mereka adalah orang wed (asli) Sading dan mereka berbanjar adat dan memiliki setra (kuburan). Jalinan tradisi - tradisi Hindu Bali tetap dipakai seperti ornamen-ornamen gereja, tradisi ngejot, mebat , medengokan, megebagan ataupun metulung atau nguopin bahkan saling undang pun terintegrasi secara melekat.

Berdasarkan uraian di atas, memberi kesimpulan pada peneliti, bahwa kekrabatan yang ada di Desa Sading terjalin dan terpelihara dengan baik dengan menerima perbedaan yang ada ,5) Nilai musyawarah / menyelesaikan konflik tanpa kekerasan (secara damai /bersahabat), Musyawarah dalam bentuk sangkep/paum masih sangat dipegang oleh masyarakat Desa sading dalam menyelesaikan seluruh persoalan yang ada. Hal ini dapat kita cermati dari jenis-jenis aktivitas sangkep di desa sading seperti; 1) sangkep banjar adat (sangkep bulanan) adalah sangkep di lingkungan banjar adat yang pesertanya adalah krama banjar adat biasanya lingkup acara rapat sangat padat karena terkait dengan hak dan kewajiban sebagai krama banjar. Sangkep ini secara rutin diadakan setiap bulan yang mengambil hari setiap tumpek atau 1 atau 2 hari setelah hari tumpek., 2) sangkep tunggal yang diadakan oleh banjar adat juga akan tetapi permasalahan yang dikaji atau yang dibahas adalah hah-hal yang harus disikapi segera seperti ; konflik, batas wilayah terganggu atau pengajuan calon kelian adat atau kepala lingkungan. Sebelum diadakan sangkep tunggal biasanya dilakukan rapat pendahuluan melalui pertimbangan tokoh-tokoh adat atau unutuk di banajar adat negari di sebut dengan sapta penghulu.

Disamping sangkep di banjar adat ada lagi sangkep di lingkungan banjar Pemetang dasan. Untuk sangkep-sangkep di lingkungan desa adat seperti ; rapat prajuru adat, rapat Panca Tanda, rapat krama Pura desa, rapat krama banjar penyanggra semuanya terwakili oleh masing krama banjar adat yang ditunjuk.

Berdasarkan uraian di atas, dapat disimpulkan bahwa sistem musyawarah melalui sangkep/paum adalah sudah mentradisi dan menjadi terdepan ketika memutuskan permasalahan yang terjadi, sebagai upaya menjaga ketentraman dan juga kestabilan dalam masyarakat juga terciptanya masyarakat yang madani, 6) Berpikir kritis (rasa ingin tahu),Sikap dan tindakan yang seallu berupaya untuk mengetahui lebih mendalam dan luas dari sesuatu yang dipelajari, dilihat, dan didengar. Hal ini tercermin dari kajian sebelumnya, bahwasannya masyarakat Desa Adat Sading memiliki tradisi-tradisi yang sarat dengan keteladanan dan pedoman hidup yang bisa dijadikan dasar untuk mengkaji dan menggali lebih luas akan makna kehidupan sosial bermasyarakat dan juga kedekatan dengan Tuhan.

Dari tradisi - tradisi yang ada Desa Sading dituntun dan dibentuk untuk peka terhadap realitas yang terjadi ditengah-tengah kehidupan masyarakat tidak hanya disuguhkan hal-hal atau nilai-nilai religius akan tetapi juga tersirat dan tersurat makna sosial dan kebudayaan yang bisa dikaji secara mendalam ,sehingga tidak bersifat kaku. Hal ini dapat kita cermati dari tinjauan awig-awig Desa Adat Sading yang selalu ditinjau kembali atau dibuatkan penyacah awig atau diputuskan melalui perarem. Kehadiaran lembaga adat Panca Tanda sebagai lembaga adat yang mempuyai fungsi menampung seluruh aspirasi masyarakat, mengesahkan program kerja bendesa adat dan melaksanakan pemilihan bendesa adat sekaligus mengawasi kelian desa adat atau bendesa adat. Hal ini muncul seiring dengan perkembangan dan dinamisasi masyarakat di desa sading.

Hal ini sejalan dengan fungsi awig-awig dalam konteks masyarakat yang dinamis oleh Sudantra (2010: 60) ada dua yakni; 1) awig-awig sebagai alat kontrol sosial yang berpija pada asumsi bahwa awig-awig mempunyai kemampuan mengontrol perilaku krama desa dan menciptakan suatu kesesuaian daam perilaku mereka, preventif maupu refresif, 2) fungsi saranna untuk mengubah masyarakat (social engineering), kemampuan untuk 
merespon dan mengantisipasi arus prubahan dalam masyarakat yang sangat problematik dan semakin kompleks di masa yang akan datang.

Dari ilustasi tersebut mengindikasikan masyarakat desa Sading dituntut terus berkembang dan berkembang tidak hanya menerima begitu saja apa yang sudah diwarisi secara turun temurun akan tetapi harus bisa mengkaji dan mendalami serta mendapatkan ide baru untuk kemajuan desa, 7) Kemauan dan kemampuan berpartisipasi dalam kehidupan bermasyarakat (Cinta tanah air dan peduli lingkungan),"Cinta tanah air adalah cara berpikir, bersikap dan berbuat yang menunjukkan kesetiaan, kepedulian, dan penghargaan yang tinggi terhadap bangsa Indonesia, lingkungan fisik, sosial , budaya, ekonomi dan politik bangsa". (Atmadja, 2017: 69). Cinta tanah air yaitu mengenal dan mencintai tanah air wilayah nasionalnya ataupun lingkungannya sendiri sehingga selalu waspada dan siap membela tanah air indonesia dan lingkuangan sekitarnya, terhadap segala bentuk ancaman, tantangan, hambatan dan gangguan yang dapat membahayakan kelangsungan hidup masyarakat luas, bangsa dan negara oleh siapapun dan dari manapun sehingga diharapkan setiap masyarakat dan warga negara Indonesia umumnya akan mengenal dan memahami wilayah nusantara, memelihara, melestarikan, mencintai lingkungannnya dan senatiasa menjaga nama baik dan mengharumkan Negara Indonesia di mata dunia (Suwarno, 2000:12).

Dengan demikian sikap mencintai bangsa dan negara tanpa mengenal fanatisme kedaerahan. Cinta tanah air berarti cinta pada lingkungan dimana kita berada sampai ujungnya mencintai negara tempat kita memperoleh sumber penghidupan dan menjalani kehidupan sampai akhir hayatnya. Kecintaan terhadap tanah air bearti memiliki kepekaan dan kepedulian terhadap lingkungannya untuk senatiasa berbuat yang terbaik. Sikap yang menjaga negarany tetap aman, sentosa, sejahtera damai serta mengembangakan sikap tanggap dan waspada terhadap segala unsur-unsur negatif yang bisa meronggrong persatuan dan kesatuan bangsa baik dari dalam maupun yang berasal dari luar.

Berdasarkan uraian di atas, sikap rasa cinta tanah air sudah menyatu dalam diri masyarakat Sading dalam mengaktualisasikan kemampuan sebagai potensi diri untuk berbakti melalui karma baik kepada masyarakat,8 )Nilai tanggung jawab, Nilai tanggung jawab diartikan sebagai sikap dan perilaku seseorang untuk melaksanakan tugas dan kewajiban, yang seharusnya dilakukan terhadap diri sendiri, masyarakat, lingkungan( alam, sosial, dan budaya), negara dan Tuhan yang Maha Esa. (Atmadja, 2017:69). Tanggung jawab adalah kesadaan manusia akan tingkah laku atau perbuatannya yang diengaja maupun yang tidak disengaja. Tanggung jawab juga beartiberbuat sebagai wujudan kesadaran akan keawjibannya.ini mengingat manusia adalah makhluk individu dan makhluk sosialdan juga sebagai makhluk Tuhan. Manusia mempunyai tuntutan besar untuk bertanggung jawabmengingat manusia akan mementaskan peranan dalam sejumlah konteks sosial individu, sosial maupun dalam hubungannnya dengan Tuhan.

Tanggung jawab dalam konteks pergaulan manusia adalah keberanian. Orang yang bertanggung jawab adalah orang yang berani menanggung resiko atas segala yang menjadi tanggung jawbnya, la jujur terhadap dirinya dan jujur terhadap orang lain, tidak pengecut dan mandiri. Dengan rasa tanggung jawab, orang yang bersangkutan akan berusaha melalui seluruh potensi dirinya. Selain itu orang yang bertanggung jawab adalah orang yang berkorban demi orang lain.

Sikap dan nilai tanggung jawab terbentuk dalam ikatan-ikatan sosial yang ada pada tingkat keluarga. Tanggung jawab sudah terbentuk ketika kita mendapatkan status baru "mapikuren" membentuk keluarga baru. Mereka sudah punya kewajiban untuk terjun sebagai krama adat banjar. Beberapa tugas dan tanggung jawab dengan sendirinya sudah didapat sebagai krama pengarep. Segala yang berbentuk sebagai ayahan banjar maupun ayahan desa ataupun merajan/dadia sudah mulai melekat sehingga menjadi terbiasa didengar dan dilaksanakan tanpa ada paksaan sehingga menjadi kewajiban.

Pembelajaran nilai tanggung jawab melalui penghormatan terhadap tugas dan tanggung jawab para prajuru desa yang menetapkan awig-awig sebagai patokan dalam bertindak dalam masyarakat. Prajuru desa dan masyarakat Desa Sading secara bersama 
menjalankan hak dan kewajiban dengan penuh rasa tanggung jawab sehingga tercipta sading yang Jagadhita.

Dari kedelapan nilai karakter yang terdapat pada kearifan lokal Desa Adat Sading dapat diuraikan melalui tabel 4.06 berikut ini:

Tabel $01 \quad$ Nilai-nilai Karakter yang berkembang melalui Kearifan Lokal pada Lembaga Desa Adat Sading.

\begin{tabular}{|c|c|c|}
\hline No. & Nilai Karakter & Sumber Nilai \\
\hline 1 & Nilai Ketuhanan (religius) & $\begin{array}{l}\text { Teraktualisasi melalui aktivitas, ngayah, } \\
\text { mepeed, mesanti, mekidung, makemit, } \\
\text { peletan, ampilan, lunga, ngunya, } \\
\text { melancaran, membentuk sikap masyarakat } \\
\text { untuk bakti sweca dan tindih. }\end{array}$ \\
\hline 2 & $\begin{array}{l}\text { Mengahargai } \\
\text { demokrasi) }\end{array}$ & $\begin{array}{l}\text { Terjadi melalui tradisi-tradisi adat } \\
\text { masyarakat Desa Sading melalui aktivitas } \\
\text { adat sangkep/paum, dedia/merajan, } \\
\text { pemetangdasan desa, dadian, } \\
\text { sekaa-sekaa yang pengambilan } \\
\text { keputusannya melalui sangkep/paum rwa } \\
\text { bhineda, menyama braya. }\end{array}$ \\
\hline 3 & $\begin{array}{l}\text { Menerima dan memahami perbedaan } \\
\text { kultur dalam masyarakat (nilai } \\
\text { toleransi) }\end{array}$ & $\begin{array}{l}\text { Tercermin melalui tradisi dalam praktek } \\
\text { kehidupan masyarakat Desa Sading seperti } \\
\text { saling ngejot (antar agama yang berbeda } \\
\text { ketika ada kegiatan agama). Adanya tempat } \\
\text { suci gereja sejumlah } 4 \text { buah, ornamen- } \\
\text { ornamen gereja yang memakai ornamen } \\
\text { hindu, acara saling undang untuk mebat, } \\
\text { Rwa Bhineda. }\end{array}$ \\
\hline 4 & Peduli Sosial & $\begin{array}{l}\text { Dilakukan melalui kegiatan urun dana } \\
\text { kematian, medengokan, } \\
\text { magebagan, kwangen, tedun, nyama braya, } \\
\text { lascarya. }\end{array}$ \\
\hline
\end{tabular}

5 Tanggung Jawab Terjadi melalui tradisi adat ayah-ayahan( hak dan kewajiban) banjar, tagel, desa, pemetangdasan, pura. Preti sentana (ampilan, merawat dan memperbaiki pura, peletan maupun pengerob).

\begin{tabular}{lll}
\hline 6 & Cinta Tanah Air & $\begin{array}{l}\text { Diwujudkan melalui tradisi tindih, bhakti, } \\
\text { wirang, ngayah, sidhikara. }\end{array}$ \\
\hline 7 & Bersahabat cinta damai & $\begin{array}{l}\text { Musyawarah/sangkep, dharmasuaka, ngidih } \\
\text { pelih, mesuaka, nyama braya, paras paros } \\
\end{array}$ \\
& $\begin{array}{l}\text { sarpanaya, sagilik saguluk salunglung } \\
\text { sabayantaka }\end{array}$ \\
\hline 8 & Ingin tahu & Jengah, lek, apa ane sing dadi pelajahin, ...
\end{tabular}

\section{SIMPULAN DAN SARAN}

Dari analisis penelitian ini dapat ditarik suatu kesimpulan sebagai berikut:

1. Pemetang dasan sebagai dresta kuno sekaligus dresta desa yang ada di Desa Adat Sading yang terpelihara secara turun temurun dan tertuang dalam awig-awig Desa Sading didalam mengorganisasikan dan mengelola adat dan budaya di Desa Sading. 
Pemetang dasan dalam aktiviatasnya bersumberkan pada ajaran agama Hindu yakni Tri Hita Karana, yakni keharmonian pada parhyangan , pawongan dan palemahan yang dalam aktualisasi sosio kemasyarakatan tergambar dalam banjar pemetang dasan (pembagian wilayah dan tanggung jawab), dulun desa (orang-orang yang berhasil dan dipercaya di tingkat desa)) panca tanda (badan yang memilih kelian desa adat dan menampung aspirasi), sapta penghulu (penasehat kelian adat di banjar adat), tindih (setia), bhakti ( berserah diri), sweca (iklas), nguopin ( saling bantu antar sesama manusia), ngayah ( gotong -royong yang secara iklas di pura atau di grya /puri), mekemit ( bermalam suntuk), maegebagagan ( wujud peduli sosial untuk menemani anggota keluarga yang berduka), memunjung (membawa sesajen kepada sesama kerabat keluarga), melancaran (keliling desa untuk keselamatan desa), mepeed/melelod ( membawa sesajen/gebogan sebagai wujud bhakti kepada Tuhan), ngejot (saling memberi dan menerima) maupun ungkapan -ungkapan tradisional seperti ; eda ngaden awak bisa, depang anake ngadanin ( jangan sombong), puntulpuntule tiuk yen suba sangih pasti mangan (jangan putus asa untuk belajar), rwe bhineda (keberagaman), celebingkah beten biu, gumi linggah ajak liu ( mengakui keberagaman), mekecuh marep menek (instrosfeksi), karma phala (hukum sebab akibat dari perbuatan yang kita lakukan), Tri Hita Karana (tiga penyebab keharmonisan), metilesang dewek (tahu diri), muani negen, luh nyuun ( kesetaraaan gender), mesikut di awak (introsfeksi), jele melah pada gelahang ( rasa kebersamaan), Paras-paros ( tenggang rasa), asah,asih, asuh (hak dan kewajiban yang sama), menyama braya (persaudaraan), masidhikara (persatuan), sagilik saguluk (bersatu padu secara bulat dan utuh), nindihin patut (membela kebenaran), Lascarya (iklas).

2. Nilai -nilai sosio kultural sebagai nilai kearifan lokal Desa adat Sading terimplementasi menjadi delapan nilai karater sebagai nilai luhur bangsa seperti; : (1) Nilai ketuhanan (religius), (2) Toleransi, (3) Demokratis, (4) Tanggung Jawab, (5) Peduli sosial, (6) Berpikir kritis/rasa ingin tahu, (7) menyelesaikan konflik secara damai (8) kemauan dan kemampuan berpartisipasi dalam masyarakat/cinta Tanah air.

3. Keberlangsungan adat dan budaya sebagai nilai-nilai luhur tidak bisa berjalan sepihak, oleh karenanya perlu integrasi semua komponen yang ada di desa maupun pemerintah itu sendiri yang senantiasa proaktif untuk membuat terobosan dalam pelestarian adat dan budaya.

\section{DAFTAR RUJUKAN}

Atmadja. 2017. "Agama Hindu, Pancasila dan Kearifan Lokal Pondasi PendidikanKarakter. Singaraja : Pustaka Larasan.

Widyanti, Triani. 2015. "Penerapan Nilai-nilai Kearifan Lokal dalam Budaya Masyarakat Kampung Adat Cireundeu Sebagai Sumber Pembelajaran IPS” Vol.24 ,No.2. Edisi Desember 2015.

Budiwaty Suci. 2011. "Unsur Pengembangan Karakter Bangsa Dalam Kearifan Lokal Bali”. Vol. 4 Oktober 2011. Depok

Ekowarni, Endang. 23 Juni 2011. Pengembangan Nilai-nilai luhur Budi Pekerti sebagai Karakter Bangsa. http://belanegarari.wordpress.com/2009/-08/25/

Geerts, Clifford, 2017, Sistem Kekerabatan di Bali, Denpasar: Udayana University Press

Permendiknas, 2010. Panduan Pendidikan Karakter, Jakarta: Sekmendiknas.

Komalasari, 2017, Pendidikan Karakter, Bandung : PT. Refika Aditama

Korn, V.E. 2017. "Hukum Adat (Het Adatrecht van Bali) Jilid I". Denpasar : Udayana University Press. 
PIPS, Vol. 2 No. 1, Bulan April Tahun 2018

Korn, V.E. 2017. "Hukum Adat (Het Adatrecht van Bali) Jilid II". Denpasar : Udayana University Press. 